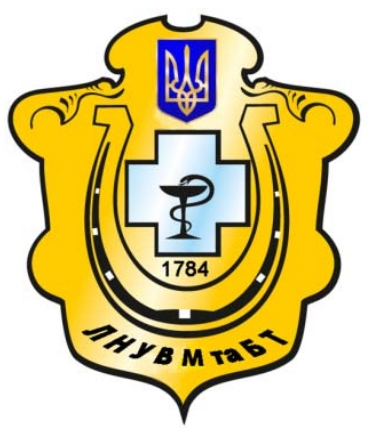

Науковий вісник Львівського національного університету ветеринарної медицини та біотехнологій імені С.3. Гжицького

Scientific Messenger of Lviv National University of Veterinary Medicine and Biotechnologies named after S.Z. Gzhytskyj

doi:10.15421/nvlvet7002

ISSN 2413-5550 print

ISSN 2518-1327 online

$\underline{\text { http://nvlvet.com.ua/ }}$

УДК 619:636.1

\title{
Визначення терміну зберігання та стабільності інфекційної активності культуральних антигенів штаму ГВК 1 Ж та клону ГВК 2 ТT для постановки РДП
}

\author{
А.А. Антонюк, О.В. Дишкант, О.А. Нікітін \\ antonyuk.doc@mail.ru \\ Житомирський національний агроекологічний університет, \\ Старий бульвар, 7, м. Житомир, 10002, Україна
}

\begin{abstract}
Встановлено, щзо джерелом збудника ГВК-1 та ГВК-2 є жеребиі та кобили старше року. Удосконалили раніше запропоновані серологічні методи діагностики. 3 метою отримання антигенів проведено культивування герпесвірусу першого типу на перещеплювальній культурі клітин епітелію тестикули поросяти. Герпесвірус другого типу - на перещеплювальній культурі клітин епітелію трахеї теляти. Для визначення інфекиійної активності культуральної вірусовмісної рідини проводили в реакції гемаглютинації з суспензією еритроцитів коня. Вірусні антигени для постановки реакції дифузної преичипітації, щуодо герпесвірусної інфекції першого та другого типу у коней досліджували на мікробну контамінацію.

Виявлено, щуо зберігання культурального консервованого антигену ГВК 1 в замороженому стані при температурі мінус $18{ }^{\circ} \mathrm{C}$ можна проводити протягом 12 місяиів, оскільки інфекційна активність його в нативному стані не змінилаль протягом вказаного періоду.

3'ясовано, щңо при концентруванні антигену ГВК 1 оптимальне його розведення становить 1:20. При оціниі антигена ГВК 2 придатним для постановки реакиії дифузійної прецчипітаиії (РДП) є його концентрачія від 1:60 до 1:20. Концентрований антиген ГВК 2 в 30 раз, придатний до використання в розведенні 1:2 в РДП, а при розведені 1:4 не завжди утворює специфічну лінію прецииітації.

Ключові слова: герпесвірус, інфекиія, культивування, вірусна рідина, антиген, жеребиі, кобили, реакція дифузійної преи̧ипітації (РДП), робоча доза, суспензія еритроцитів, лінія преципітації, гіперімунна сироватка, живильне середовище.
\end{abstract}

\section{Определение срока хранения и стабильности инфекционной активности культуральных антигенов штамма ГВК 1 Ж илонам ГВК 2 ТT для постановки РДП}

\author{
А.А. Антонюк, О.В. Дышкант, О.А. Никитин \\ antonyuk.doc@mail.ru \\ Житомирский наииональный агроэкологический университет, \\ Старый бульвар, 7, г. Житомир, 10002, Украина
}

\begin{abstract}
Установлено, что источником возбудителя ГВК-1 и ГВК-2 есть жеребиы и кобыль старше года. Усовершенствовали раньше предложенные серологические методы диагностики. С иелью получения антигенов проведено культивирование герпесвируса первого типа на перевиваемой культуре клеток эпителия тестикуль поросенка. Герпесвирус второго типа на перевиваемой культуре клеток эпителия трахеи теленка. Для определения инфекиионной активности культуральной вирусовместительной жидкости проводили в реакиии гемагглютинации с суспензией эритроцитов коня. Вирусные антигены для постановки реакиии диффузионной прецииитащчи к герпесвирусной инфекции первого и второго типа у лошадей исследовали на микробную контаминацию.
\end{abstract}

Citation:

Antonuk, A., Dyshkant, O., Nikitin, O. (2016). Determination of expiration and stability of infectious activity of cultural antigens of stamm of EHV date $1 \mathrm{G}$ and clonals of EHV 2 TT for raising of RDP. Scientific Messenger LNUVMBT named after S.Z. Gzhytskyj, 18, 3(70), 8-12. 
Выявлено, что сохранения культурального консервированного антигена ГВК 1 в замороженном состоянии при температуре минус $18^{\circ} \mathrm{C}$ можно в течение 12 месяцев, поскольку инфекционная активность его не снизилась после иести месячного хранения в замороженном состоянии.

Выяснено, что при концентрации антигену ГВК 1 оптимальное его разведение представляет 1:20. При оценке антигена ГВК 2 пригодной для постановки реакции диффузионной преципитации (РДП) является его концентрация от 1:60 до 1:20. Концентрированный антиген ГВК 2 в 30 раз, пригодный к использованию в разведении 1:2 в РДП, а при разведеннье 1:4 не всегда образует специффическую линию прецииитации.

Ключевые слова: герпесвирус, инфекция, культивирование, вирусная жидкость, антиген, жеребиьл, кобыль, реакиия диффузионной преципитации (РДП), рабочая доза, суспензия эритроцитов, линия преципитации, гипериммунная сыворотка, питательная среда.

\title{
Determination of expiration and stability of infectious activity of cultural antigens of stamm of EHV date $1 \mathrm{G}$ and clonals of EHV 2 TT for raising of RDP
}

\author{
A. Antonuk, O. Dyshkant, O. Nikitin \\ antonyuk.doc@mail.ru
}

Zhytomyr national agroecological university,

Staryj Boulevard, 7, Zhytomyr, 10002, Ukraine

\begin{abstract}
Getting a culture herpesviridae antigens first and second types is possible using cell cultures inoculated epithelial pig testicles and tracheal calf respectively. The incubation herpesviridae first and second types should be conducted on the above lines in cell culture incubator at a temperature of $37,5^{\circ} \mathrm{C}$ for up to 10 days. To maximize the release of virus from cell culture fluid viral after incubation need three frozen at temperatures from $-18{ }^{\circ} \mathrm{C}$ to $+20^{\circ} \mathrm{C}$. The resulting liquid is purified viral the culture by centrifugation. Determining the infectious activity of the culture liquid viral performed in response hemagglutination of horse erythrocytes suspension, and the material is titrated to 1: 128 in the two recurrence. Accounting reaction was performed at 2, 4, 6 and 8 hours. Infectious material volumetric activity was 1:4. Getting antigens envisages concentrating liquid viral culture fluid by reverse dialysis. To do this, conducted a study to identify the optimal concentration of antigen suitable for setting reaction diffusion precipitation. At 1:10 antigen concentration result of different reactions, depending on the account of the diffusion precipitation reactions. When concentration of EHV-1 antigen was found that the optimum dilution for its RDP is 1:20. In assessing the EHV-2 antigen, found that suitable for setting reaction diffusion precipitation RDP is an antigen concentrated from 1:60 to 1:20. In practical terms, most rational use of antigen, concentrated 20 times.Keeping culture antigens can be conducted frozen at minus $18^{\circ}$ $C$, for 12 months because after six months of storage of the frozen infectious activity was not decreased. And in research in 12 months noted a line of precipitation in native samples and serum diluted 1:2. Working antigens for diffuse precipitation reaction must be sterile on various forms of bacteria and fungi. Therefore, samples of viral antigens were plated on agar culture media for general purpose (plain agar), after having spent preserving antigen using $0.01 \%$ solution mertiolyatu rate of $0.1 \mathrm{sm}^{3} / 1 \mathrm{sm}^{3} \mathrm{culture}$ fluid. Using such an environment can detect material in the test organisms belonging to different morphological groups. Research sterility subjected to viral antigens, herpesviridae infection on the first type of herpesviridae infection and the second type.

Key words. Herpesvirus, infection, culturing, viral liquid, antigen, stallions, mares, reaction diffusion precipitation (PRD), the working dose, suspension of red blood cells, line of precipitation, hyperimmune serum, culture medium.
\end{abstract}

\section{Ветуп}

Конярство є однією із важливих галузей сільського господарства України. Останнім часом в результаті інтенсивного ведення конярства спостерігається тенденція до поширення латентного перебігу інфекційних захворювань (Galatjuk and Kan'ovs'kij, 2003). Ceред них найбільш поширеними є герпесвірусні інфекції першого (ГВК-1) та другого типу (ГВК-2) у коней. Герпесвірусні інфекції завдають значних економічних збитків конярству, які складаються з втрати відтворювальної здатності конематок, вибраковки цінних племінних тварин, затрат на проведення ветеринарносанітарних заходів (Apatenko, 2003).

В природних умовах вірус вражає коней, ослів і мулів незалежно від статі, породи та віку. Чистокровні коні більш сприйнятливі до збудника, ніж напівкровні і аборегенні породи. Захворювання, що виникло в конегосподарстві, набуває характеру стаціонарної інфекції. Гострий перебіг хвороби чергується 3 періодами прихованого атипового прояву, що значно ускладнює постановку діагнозу (Busol et al.,1996; Robinson, 2007).

У системі заходів боротьби з герпесвірусною інфекцією важливе значення має надійна діагностика хвороби. На сьгоднішній день ідентифікація збудника віруса герпеса проводиться в спеціалізованих лабораторіях і включає вірусологічні (культуральні) дослідження та молекулярно-генетичні (ПЛР). На місцях проводять клініко-епізоотологічні та серологічні дослідження. Проте запропоновані раніше серологічні методи діагностики вимагають подальшого удосконалення i це також стосується засобів та методів профілактики хвороби (Busol et al., 1996).

Актуальність теми. Серед найбільш поширених інфекційних захворювань коней $є$ герпесвірусні інфекції. Досліди, що проведені доцентом М.Л. Радзиховським, вказують на те, що жеребці $є$ переносниками герпесвірусів, а зараження відбувається саме під час парування тварин (Radzyhovs'kyj, 2006). В наших дослідженнях, які 
проводяться 32004 року встановлено, що джерелом збудника ГВК-1 та ГВК-2 $є$ жеребці та кобили старше року. Це є надзвичайно актуальним питанням ветеринарної науки і практики оскільки потребує удосконалення лабораторної діагностики ГВК-2 та лікувально-профілактичних заходів.

Мета та завдання дослідження. Удосконалити лабораторні методи діагностики герпесвірусних інфекцій коней, зокрема обумовленої ГВК-1 чи ГВК2 (або одночасно ураженням обома типами).

\section{Матеріал і методи досліджень}

Дослідження виконували згідно з планом науководослідних робіт кафедри мікробіології, фармакології та епізоотології Житомирського національного агроекологічного університету та на базі Нагірянської філії ПрАТ «Райз-Максимко», с. Нагірянка Чортківського району Тернопільської області. Провели епізоотологічний моніторинг сумісного перебігу герпесвірусної інфекції 1-го та 2-го типів та удосконалили існуючі лабораторні методи діагностики.

\section{Результати та їх обговорення}

3 метою отримання антигенів ми проводили культивування герпесвірусу першого типу на перещеплювальній культурі клітин епітелію тестикули поросяти. Герпесвірус другого типу культивували на перещеплювальній культурі клітин епітелію трахеї теляти. Інкубацію герпесвірусів першого та другого типів проводили на вищезгаданих лініях культур клітин в термостаті при температурі $37,5^{\circ} \mathrm{C}$ терміном до $10-$ ти діб. Після інкубування вірусовмісну культуральну рідину тричі переморожували при температурних режимах від $-18^{\circ} \mathrm{C}$ до $+20^{\circ} \mathrm{C}$, для максимальної руйнації клітин і звільнення вірусу. Отриману культуральну вірусовмісну рідину центрифугували $(10-20$ хвилин при 2000 об/хв., 200g) для очищення від великих частин. Для визначення інфекційної активності культуральної вірусовмісної рідини проводили постановку реакції гемаглютинації з суспензією еритроцитів коня. Реакцію ставили по загальноприйнятій методиці в 96-лункових мікропланшетах, розтитровуючи досліджуваний матеріал до 1:128 в двох повторюваностях. Облік реакції проводили через 2, 4, 6, та 8 годин. Результати реакції представлені на рисунку 1.

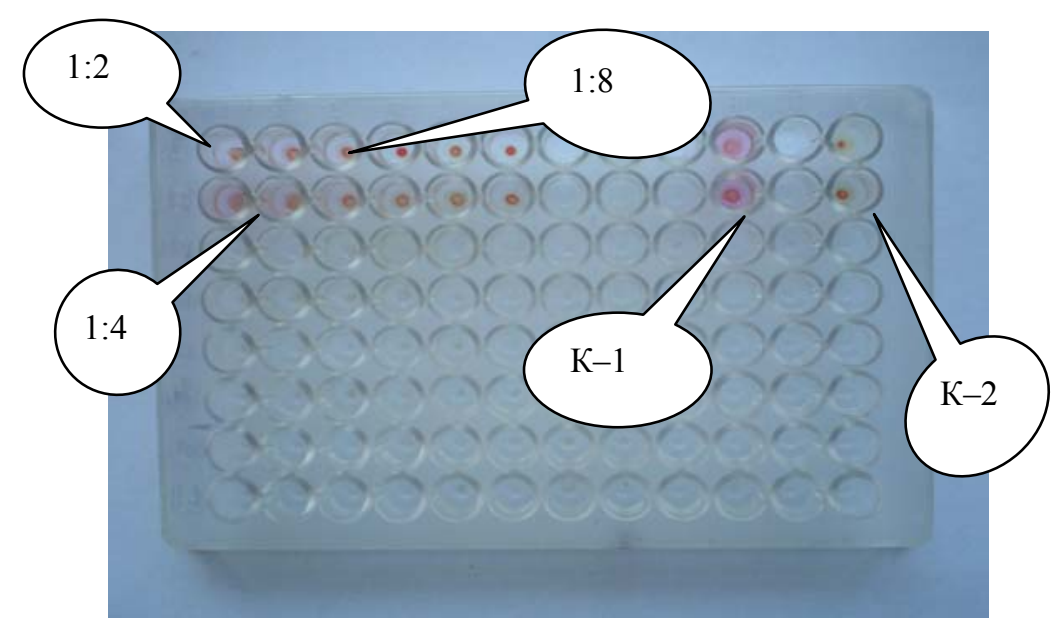

Рис. 1. Аглютинація еритроцитів коня герпесвірусом коней.

Примітки: «К-1»- контроль (фізіологічний розчин + вірусна рідина + суспензія еритроцитів). «К-2»- контроль (фізіологічний розчин + суспензія еритроцитів), на спонтанну аглютинацію еритроцитів.

3 рисунка 1 видно, як в лунці 2, що відповідає розведенню 1:4, відмічається аглютинація еритроцитів, які осідають у вигляді рівномірної плівочки утворюючи так звану «парасольку». Починаючи з лунки три що відповідає розведенню 1:8 відмічається осідання еритроцитів у вигляді «гудзика», що вказує на відсутність аглютинації.

Отже, інфекційна активність титрованого матеріалу становить 1:4.

Наступним етапом отримання антигенів було проведення концентрування вірусовмісної культуральної рідини методом зворотного діалізу рисунок 2 .

Далі проводили дослідження 3 виявлення оптимальної концентрації антигену, придатного для постановки реакції дифузійної преципітації таблиця 2. 3 даних таблиці видно, що при концентрації антигенів 1:10 результат реакції різний в залежності від проведення обліку реакції дифузійної преципітації.

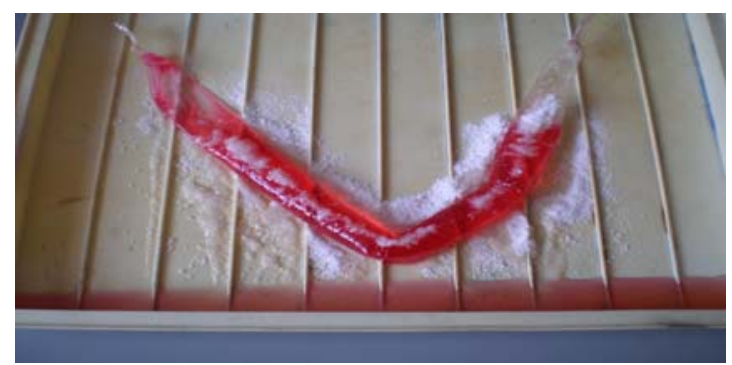

\section{Рис. 2. Концентрування культуральної вірусо-} вмісної рідини

При концентруванні антигену ГВК-1 було встановлено, що оптимальне його розведення для проведення РДП становить 1:20. При оцінці антигена ГВК-2, було встановлено, що придатним для постановки реакції дифузійної преципітації РДП є антиген, концентрований від 1:60 до 1:20. 3 практичної точки зору 
найраціональніше використовувати антиген, концентрований у 20 разів.

Результати щодо визначення робочої концентрації культуральних антигені ГВК 1та ГВК 2 для постановки РДП представлені в таблиці 1.

Таблиия 1

Результати визначення робочої дози (концентрації) антигену для постановки РДП

\begin{tabular}{|c|l|l|c|c|}
\hline \multirow{2}{*}{$\begin{array}{c}\text { Концентру- } \\
\text { вання вірусов- } \\
\text { місної рідини }\end{array}$} & \multicolumn{4}{|c|}{ Результат через год. } \\
\cline { 2 - 5 } & 24 & 48 & 72 & 96 \\
\hline $1: 100$ & $\pm \pm * / \pm *$ & $\pm / \pm$ & $\pm / \pm$ & $-/-$ \\
\hline $1: 80$ & $\pm / \pm$ & $\pm / \pm$ & $\pm / \pm$ & $-/-$ \\
\hline $1: 60$ & $\pm /+$ & $\pm /+$ & $+/+$ & $\pm / \pm$ \\
\hline $1: 30$ & $\pm /+$ & $+/+$ & $+/+$ & $\pm /+$ \\
\hline $1: 20$ & $+/ \pm$ & $+/+$ & $+/+$ & $+/ \pm$ \\
\hline $1: 10$ & $+/-$ & $-/-$ & $\pm / \pm$ & $-/-$ \\
\hline
\end{tabular}

Примітка: *-ГВК $1 ; * *-$ ГВК 2.

Зберігання культуральних антигенів ми проводили в замороженому стані при температурі мінус $18^{\circ} \mathrm{C}$, попередньо проводили консервування антигену, за допомогою $0,01 \%$ розчину мертіоляту 3 розрахунку $0,1 \mathrm{~cm}^{3} / 1 \mathrm{~cm}^{3}$ культуральної рідини, для знищення додаткової мікрофлори. Кількість консерванту який необхідно додавати визначали поступовим збільшенням дози розчину мертіоляту, контролюючи висіванням антигену на поживні середовища.

Отримання антигену передбачає перевірку на мікробну стерильність Зразки вірусних антигенів 3 в

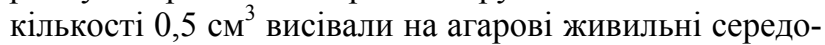
вища загального призначення (МПА). Використання такого середовища дозволяє виявити в досліджуваному матеріалі мікроорганізми, що належать до різних морфологічних груп. Дослідженню на стерильність піддавали вірусні антигени, щодо герпесвірусної інфекції першого типу та герпесвірусної інфекції другого типу (рисунок 3).

3 метою визначення терміну зберігання та придатності антигенів через кожні 6 місяців проводили постановку реакції дифузійної преципітації розтитрову- ючи антиген та сироватки до розведення 1:32 (рисунок 4).

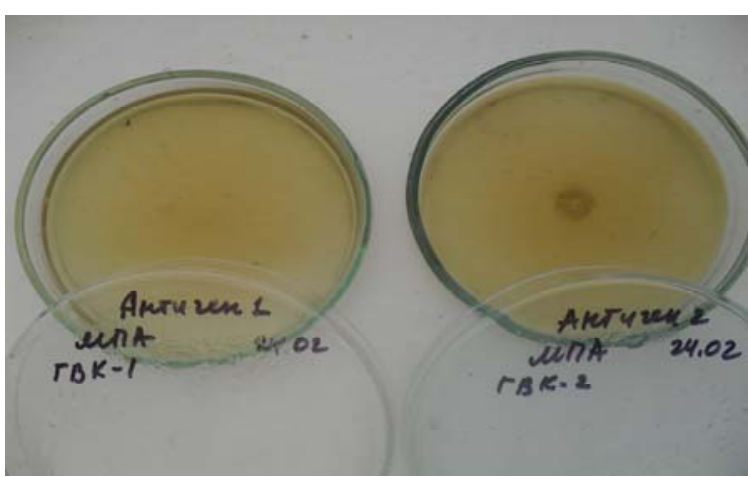

Рис. 3. Результат висіву культуральних антигенів ГВК 1 та ГВК 2 типів 3 вмістом 0,01 \% розчину мертиоляту

Результати обліку реакції дифузійної преципітації 3 титрованим антигеном ГВК 1 та гіперімунними сироватками представлені в таблиці 2.

3 даних таблиці 2 видно, що протягом шести місяців зберігання антигену в замороженому стані інфекційна активність його не знизилася. При проведені дослідження через 12 місяців лінію преципітації відмічали в нативних пробах та в розведені сироватки $1: 2$.

Отже, збереження культурального консервованого антигену ГВК 1 в замороженому стані при температурі мінус $18{ }^{\circ} \mathrm{C}$ можна протягом 12 місяців.

Результати обліку реакції дифузної преципітації з титрованим антигеном ГВК 2 та гіперімунними сироватками представлені в таблиці 3. 3 якої видно, що концентрований антиген ГВК 2 в 30 раз, придатний до використання в розведенні 1:2 для постановки РДП, а при розведені 1:4 не завжди утворює специфічну лінію преципітації тобто відмічається не характерний прояв реакції.
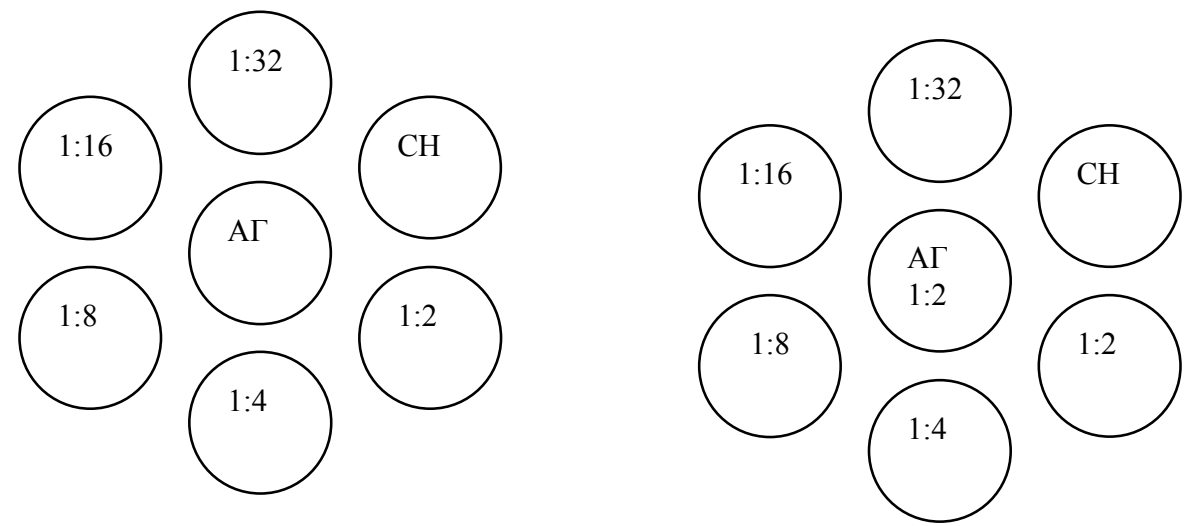

Рис 4. Схема постановки РДП

де, АГ - антиген нативний, АГ - антиген в розведені 1:2; $\mathrm{CH}$ - сироватка нативна серопозитивна; 1:2-1:32 - розведення позитивної сироватки. 
Таблиия 2

Стабільність та термін зберігання культурального антигену ГВК 1

\begin{tabular}{|c|c|c|c|c|c|}
\hline \multirow{2}{*}{$\begin{array}{l}\text { Період } \\
\text { зберігання }\end{array}$} & \multirow{2}{*}{$\begin{array}{c}\text { Розведення } \\
\text { сироватки }\end{array}$} & \multicolumn{4}{|c|}{ Розведення антигену } \\
\cline { 3 - 6 } & $\begin{array}{c}\text { натив- } \\
\text { ний }\end{array}$ & $1: 2$ & $1: 4$ & $1: 8$ \\
\hline \multirow{3}{*}{$\begin{array}{c}\text { Перед } \\
\text { заморожу- } \\
\text { ванням }\end{array}$} & нативна & + & + & + & + \\
\cline { 2 - 6 } & $1: 2$ & + & + & + & - \\
\cline { 2 - 6 } & $1: 4$ & + & \pm & - & - \\
\hline \multirow{3}{*}{6 місяців } & $1: 8$ & \pm & - & - & - \\
\cline { 2 - 6 } & нативна & + & + & + & + \\
\cline { 2 - 6 } & $1: 2$ & + & \pm & \pm & - \\
\cline { 2 - 6 } & $1: 4$ & \pm & - & - & - \\
\hline \multirow{3}{*}{12 місяців } & $1: 8$ & \pm & - & - & - \\
\cline { 2 - 6 } & нативна & + & - & - & - \\
\cline { 2 - 6 } & $1: 2$ & + & - & - & - \\
\cline { 2 - 6 } & $1: 4$ & - & - & - & - \\
\hline
\end{tabular}

Примітка: «+»- позитивно; «-» - негативно; « \pm - сумнівно

Нами було проведено аналіз щодо збереження активності даного концентрованого антигену після заморожування і повторного його використання. При проведені реакції через 6 місяців нами було встановлено, що придатність антигену лишається без змін порівнюючи 3 вихідним матеріалом, а можливість використання антигену після 12 місячного терміну зберігання в замороженому стані змінюється не значно і дозволяє його використання у нативному вигляді. Антиген щодо діагностики герпесвірусної інфекції другого типу зберігає свою придатність для постановки реакції дифузійної преципітації протягом 6 місяців без змін порівнюючи 3 аналоговим антигеном який отримували безпосередньо перед необхідністю серологічної діагностики.

Таблиия 3

Стабільність та термін зберігання культурального антигену ГВК 2

\begin{tabular}{|c|c|c|c|c|}
\hline Період & Розведення & \multicolumn{3}{|c|}{ Розведення антигену } \\
\cline { 2 - 5 } зберігання & сироватки & нативний & $1: 2$ & $1: 4$ \\
\hline \multirow{4}{*}{$\begin{array}{c}\text { Перед } \\
\text { заморожу- } \\
\text { ванням }\end{array}$} & Нативна & + & + & \pm \\
\cline { 2 - 5 } & $1: 2$ & + & - & - \\
\cline { 2 - 5 } & $1: 4$ & \pm & - & - \\
\hline \multirow{3}{*}{6 місяців } & $1: 8$ & - & - & - \\
\cline { 2 - 5 } & Нативна & + & + & - \\
\cline { 2 - 5 } & $1: 2$ & + & - & - \\
\cline { 2 - 5 } & $1: 4$ & - & - & - \\
\hline \multirow{3}{*}{12 місяців } & $1: 8$ & - & - & - \\
\cline { 2 - 5 } & Нативна & + & - & - \\
\cline { 2 - 5 } & $1: 2$ & - & - & - \\
\cline { 2 - 5 } & $1: 4$ & - & - & - \\
\hline
\end{tabular}

Примітка: «+»- позитивно; «-»- негативно; « $\pm »-$ сумнівно.

Даний експеримент визначив і дозволив ефективно використовувати антигени ГВК-1 та ГВК-2, при необхідності, без додаткових підготовчих маніпуляцій в умовах дослідної лабораторії на період серологічних моніторингових досліджень.

\section{Висновки}

Таким чином, на основі літературних даних та проведених експериментальних досліджень щодо визначення терміну зберігання та стабільності інфекційної активності культуральних антигенів штаму ГВК 1 Ж та клону ГВК 2 ТТ для постановки РДП можна констатувати, що при концентрації антигену ГВК 1 оптимальне його розведення становить 1:20. При оцінці антигена ГВК 2 придатним для постановки реакції дифузійної преципітації (РДП) є його концентрація від 1:60 до 1:20. 3 практичної точки зору найраціональніше використовувати антиген, концентрований у 20 разів.

Збереження культурального консервованого антигену ГВК 1 в замороженому стані при температурі мінус $18^{\circ} \mathrm{C}$ можна протягом 12 місяців.

Встановлено, що концентрований антиген ГВК 2 в 30 раз, придатний до використання в розведенні 1:2 в РДП, а при розведені 1:4 не завжди утворює специфічну лінію преципітації тобто відмічається не характерний прояв реакції.

Антиген щодо діагностики герпесвірусної інфекції другого типу зберігає свою придатність для постановки реакції дифузійної преципітації протягом 6 місяців без змін порівнюючи 3 аналоговим антигеном який отримували безпосередньо перед необхідністю серологічної діагностики.

Перспективи подальших досліджень. У подальшій роботі вважаємо за необхідним провести аналіз придатності культурального антигену в інших серологічних реакціях.

\section{Бібліографічні посилання}

Apatenko, V.M. (2003). Virusnye infekcii sel'skohozjajstvennyh zhivotnyh. Har'kov: RVV HGZVA. 122-125 (in Ukrainian).

Galatjuk, O.Je. (2003). Zarazni hvorobi konej. Zhitomir: Volin' (in Ukrainian).

Galatjuk, O.Je., Kan'ovs'kij, A.I. (2003). Osnovi profilaktiki hvorob konej. Vet. Medicina. 4, 12-13 (in Ukrainian).

Robinson, Je. (2007). Gerpesvirusnye infekcii. Bolezni loshadej, sovremennye metody lechenija. M. 66-70 (in Russian).

Busol, V.O., Mandygra, M.S.,. Galatjuk, O.Je [ta in.]. (1996). Ocinka imunnogo statusu konej v normi i za pryhovanogo perebigu infekcijnoi' anemii': metod. rek. Rivne: In-t epizootologii' (in Ukrainian).

Radzyhovs'kyj, M.L. (2006). Vykorystannja RDP dlja diagnostyky u konej gerpesvirusnoi' infekcii' II typu. Naukovi ta praktychni aspekty veterynarnoi' medycyny v Ukrai'ni: Visnyk Bilocerkivs'kogo derzhavnogo agrarnogo universytetu. Bila-Cerkva. 106-109 (in Ukrainian).

Стаття надійшла до редакиії 30.09.2016 